STUDIA PRAWNO-EKONOMICZNE, t. CV, 2017

PL ISSN 0081-6841; e-ISSN 2450-8179 $\quad$ s. 311-339

DOI: 10.26485/SPE/2017/105/18

Mariusz PLICH*

Jurand SKRZYPEK**

\title{
WYKORZYSTANIE WIELOSEKTOROWYCH MODELI MAKROEKONOMICZNYCH W MODELOWANIU KRAJOWYCH SYSTEMÓW ENERGETYCZNYCH
}

\begin{abstract}
(Streszczenie)
Modele energetyczne są ważnym narzędziem badań rozwoju społeczno-ekonomicznego, zwłaszcza w kontekście bezpieczeństwa energetycznego, wyczerpywania zasobów naturalnych czy polityki klimatycznej. Celem tego opracowania jest identyfikacja pożądanych cech tych modeli i wskazanie na tym tle własności wielosektorowych modeli makroekonomicznych, decydujących o ich przydatności do budowy modeli energetycznych.

W artykule przedstawiamy system energetyczny jako wydzieloną część procesów gospodarczych, co w modelach energetycznych znajduje odzwierciedlenie w postaci wydzielenia bloku energetycznego i ekonomicznego. Analiza znanych z literatury klasyfikacji modeli energetycznych prowadzi do wniosku, że rola bloków ekonomicznych jest w nich zwykle - niesłusznie - marginalizowana. Wysoki stopień szczegółowości, jakim charakteryzują się bloki energetyczne, powinien skłaniać do konstrukcji bloku ekonomicznego z zastosowaniem ujęcia wielosektorowego o jak najwyższym poziomie dezagregacji, bo wpływa to korzystnie na jakość integracji obu bloków. W tym kontekście podkreślamy rolę wielosektorowych modeli makroekonomicznych, analizując ich podstawowe własności i prezentując przykładową postać równań popytu na energię, których wyniki mogą bezpośrednio zasilać blok energetyczny.
\end{abstract}

Słowa kluczowe: rynek energii; modele energetyczne; metody input-output; modele wielosektorowe

Klasyfikacja JEL: Q4, P47

* Dr hab., prof. UŁ, Uniwersytet Łódzki, Wydział Ekonomiczno-Socjologiczny, Instytut Ekonometrii, Katedra Teorii i Analiz Systemów Ekonomicznych; e-mail: mariusz.plich@uni.lodz.pl

** Mgr, Uniwersytet Jagielloński w Krakowie, Wydział Zarządzania i Komunikacji Społecznej, Instytut Ekonomii, Finansów i Zarządzania, Zakład Analiz Społeczno-Ekonomicznych; e-mail: jurand.skrzypek@uj.edu.p 


\section{Wprowadzenie}

Od kilkudziesięciu lat w literaturze ekonomicznej energia jest traktowana jako czynnik strategiczny dla rozwoju gospodarczego. Wynika to z bardzo wyraźnej tendencji do coraz silniejszego uzależniania produkcji i konsumpcji od zużycia energii. Tendencja ta spowodowana jest $\mathrm{z}$ jednej strony powstawaniem nowych technologii i produktów bazujących coraz szerzej na energii, a z drugiej niemożnością zastąpienia energii innymi czynnikami produkcji (brakiem substytutów). Dodatkowymi czynnikami sprzyjającymi pogłębianiu się tego uzależnienia jest wyczerpywanie zasobów i rosnące koszty emisji zanieczyszczeń ze źródeł nieodnawialnych oraz wysokie koszty produkcji energii opartej na źródłach odnawialnych. Jest więc oczywiste, że trwałość dostaw energii znajduje się w centrum uwagi polityki gospodarczej. Gwarantem tych dostaw jest sprawnie działający system energetyczny ${ }^{1}$, stwarzający warunki efektywnego pozyskiwania, przetwarzania, przesyłania i wykorzystania energii, a istotnym elementem wpływającym na efektywność są ceny energii. Wszystkie wyżej wymienione aspekty mieszczą się $\mathrm{w}$ pojęciu szeroko rozumianego bezpieczeństwa energetycznego, podlegającego zwykle regulacjom na szczeblu państwowym w ramach prowadzonej polityki energetycznej.

Skomplikowane powiązania wewnętrzne sektora energetycznego oraz uwarunkowania (powiązania) zewnętrzne, wynikające $\mathrm{z}$ jego funkcjonowania w otoczeniu innych sektorów gospodarki, wymuszają stosowanie odpowiednich narzędzi, wspomagających prowadzenie polityki energetycznej. Narzędzia te powinny ułatwiać uświadomienie i redukcję ryzyk związanych z planami i decyzjami dotyczącymi tego sektora ${ }^{2}$. Wśród tego typu narzędzi ważne miejsce zajmują modele matematyczne określane mianem modeli energetycznych. Choć ta nazwa może sugerować, że ujmują one wyłącznie powiązania wewnętrzne systemu

1 Przez system energetyczny rozumiemy tutaj wszelkie działalności polegające na pozyskiwaniu, przetwarzaniu i przesyłaniu energii wraz związaną z nimi infrastrukturą i uwarunkowaniami. Wyłączamy więc $\mathrm{z}$ tego pojęcie użytkowanie energii, pojawiające się w niektórych definicjach (Por. C. Frangopoulos, Exergy, Energy System Analysis and Optimization-Volume III: Artificial Intelligence and Expert Systems in Energy Systems Analysis Sustainability Considerations in the Modeling of Energy Systems, EOLSS Publications, 2009, s. 182; J. Krzemień, Zastosowanie generatora modeli MARKAL do optymalizacji systemów energetycznych, Journal of Sustainable Mining 2013/12/2, s. 34; H. Rechul, Systemowe spojrzenie na energetykę. Przedmiot polityki energetycznej, Nafta i Gaz Biznes 2005, nr marcowy, http://www.cire.pl/pliki/2/sys_energ.pdf; stan na 15.05.2016 r., s. 2-4).

2 J. Kamiński, Modelowanie systemów energetycznych: ogólna metodyka budowy modeli, Polityka Energetyczna 2010/13/2, s. 219-220. 
energetycznego, to uwzględniają one również jego powiązania zewnętrzne (powiązania z otoczeniem systemu, przede wszystkim z otoczeniem gospodarczym).

Powiązania zewnętrzne w modelach energetycznych mogą być uwzględniane na wiele sposobów. W najprostszym ujęciu otoczenie systemu energetycznego jest charakteryzowane za pomocą zmiennych egzogenicznych. Uruchomienie modelu musi być wówczas poprzedzone określeniem ścieżek dla zmiennych charakteryzujących funkcjonowanie otocznia gospodarczego, np. dla cen energii, tempa wzrostu gospodarczego itp. W tym przypadku nazwa model energetycz$n y$ wydaje się w pełni uzasadniona. Jeśli natomiast pewne elementy otoczenia przedstawione są w postaci zmiennych endogenicznych, to można wyodrębnić w ramach modelu dwa bloki równań: blok ekonomiczny i blok wytwarzania energii (blok energetyczny) ${ }^{3}$. Modele energetyczne tego typu należałoby określić precyzyjniej - jako modele ekonomiczno-energetyczne - w celu odróżnienia obu podejść. Mając tego świadomość, w tym opracowaniu będziemy jednak konsekwentnie określać wszelkie modele, których głównym celem jest opis systemu energetycznego, mianem modeli energetycznych.

Badania nad budową i wykorzystaniem modeli energetycznych trwają od lat siedemdziesiątych XX w. i z czasem stają się coraz intensywniejsze ${ }^{4}$. Obejmują swoim zakresem pojedyncze państwa lub ich regiony, grupy krajów lub gospodarkę światową. Prowadzone są zarówno przez instytucje rządowe, jak i pozarządowe, w tym również instytucje międzynarodowe.

Mnogość powstałych w ciągu ostatniego pięćdziesięciolecia modeli energetycznych rodzi naturalną potrzebę ich porównywania, a także systematyzowania dotychczasowych osiagnięć. W literaturze poświęconej modelom energetycznym można spotkać wiele kryteriów ich klasyfikacji. Podstawowe - w nawiązaniu do tradycji budowy modeli energetycznych - wskazuje na istnienie dwóch odmiennych podejść: nurtu inżynierskiego i nurtu ekonomicznego, jednak istotą ich rozróżnienia jest stopień szczegółowości opisu rzeczywistości przez model. Bliższa

3 Z punktu widzenia teorii modeli wielorównaniowych powiązania między tymi blokami mogą mieć charakter rekurencyjny albo współzależny. Odpowiednio do sytuacji mówi się wówczas o modelu blokowo-rekurencyjnym lub blokowo współzależnym.

4 Por. St. Rath-Nagel, A. Voss, Energy models for planning and policy assessment, European Journal of Operational Research 1981/8/2, s. 100-104; R. Miller, P. Blair, Input-Output analysis. Foundations and Extensions, Cambridge University Press, New York 2009, s. 400 -401; C. Bataille, A. Lorna, Bottom-up models of energy: across the spectrum, w: J. Evans, L.C. Hunt (red.), International Handbook on Economics of Energy, Edward Edgar, 2009, s. 257; R. Rodrigues i in., Energy-economic-environmental models: a survey, w: I. Galarraga, M. González-Eguino, A. Markandya (red.), Handbook of Sustainable Energy, Edward Elgar Publishing, 2011, s. 132 
analiza prowadzi do wniosku, że większość pozostałych kryteriów koncentruje się na własnościach matematycznych modeli (a nie na specyfice przedmiotu modelowania), a te mają przecież charakter ogólny i mogą być stosowane w odniesieniu do wszelkich dziedzin, w których wykorzystuje się modele matematyczne. Są też takie, które zwracają uwagę na sposoby modelowania bloku energetycznego w ramach modeli energetycznych. Mniejszą wagę przypisuje się natomiast do charakterystyki bloku ekonomicznego. W niniejszym opracowaniu przedstawiamy krytycznie znane z literatury, wybrane kryteria i klasyfikacje modeli energetycznych, proponując uwzględnienie w większym niż dotychczas stopniu cech bloków ekonomicznych modeli energetycznych. Zwracamy przy tym uwagę na grupę modeli określanych mianem wielosektorowych modeli makroekonomicznych (WMM), wywodzącą się z nurtu ekonomicznego, które wyróżniają się wysokim, jak na modele ekonomiczne, stopniem szczegółowości. Wykorzystanie tego typu modeli do budowy modeli energetycznych umożliwia zmniejszenie dysonansu związanego z diametralnie różnym poziomem szczegółowości utrudniającym łączenie nurtu ekonomicznego z nurtem inżynierskim.

Niniejszą pracę uporządkowano w sposób następujący:

- część druga opisuje powiązania systemu energetycznego z gospodarką narodową, ze szczególnym uwzględnieniem kierunków i rodzajów przepływów energii;

- część trzecia skupia się na prezentacji współcześnie dominujących podejść co do budowy modeli energetycznych oraz identyfikuje problemy związane z blokową konstrukcją tych modeli;

- część czwarta uwydatnia niedoskonałość dotychczas przytaczanych klasyfikacji modeli energetycznych, ze wskazaniem na marginalizację WMM;

- część piąta charakteryzuje WMM oraz określa możliwości wykorzystania tych modeli w modelowaniu krajowych systemów energetycznych.

\section{System energetyczny jako element gospodarki narodowej}

Funkcjonowanie wszelkich procesów gospodarczych uwarunkowane jest użyciem energii, co oznacza, że systemy energetyczne są powiązane ze wszystkimi komponentami gospodarek, w których zachodzą te procesy. Powiązania te przyjmuja formę przepływów (dostaw) energii. Ich znaczenie rośnie wraz z wyczerpywaniem nieodnawialnych zasobów energii i stosunkowo wolnym ich zastępowaniem przez zasoby odnawialne i niewyczerpywalne. Dlatego od dawna systemy energetyczne uznawane są za newralgiczny element każdej gospodarki narodowej. 
Silnym impulsem, który spowodował zintensyfikowanie badań ekonomicznych nad rolą energii we współczesnym świecie, był kryzys paliwowy, który dotknął kraje wysoko uprzemysłowione w latach 70 ubiegłego wieku. Rosnące uzależnienie gospodarki od jej systemu energetycznego znalazło wówczas odzwierciedlenie w specyfikacji funkcji produkcji, w której od tej pory uwzględnia się nakłady energii na równi z klasycznymi czynnikami, tj. pracą i kapitałem5. Wśród innych czynników, które w późniejszych okresach stymulowały i nadal stymulują postępy w modelowaniu systemów energetycznych, wymienia się zauważalne ryzyko wyczerpania zasobów, debaty na temat wykorzystania energii jądrowej i kwestie zmian klimatycznych ${ }^{6}$.

Uwzględnienie wpływu energii na produkcję nie wyczerpuje jednak problematyki roli systemu energetycznego w gospodarce. System energetyczny oddziałuje bowiem - bezpośrednio lub pośrednio - również na inne elementy gospodarki i jej otoczenia, a także sam od nich zależy. W rezultacie obserwuje się występowanie sprzężeń zwrotnych pomiędzy systemem energetycznym a pozostałymi elementami gospodarki. Narzędzia wspomagające podejmowanie decyzji związanych z polityką energetyczną powinny te sprzężenia uwzględniać.

Kluczowe powiązania systemu energetycznego z innymi elementami gospodarki, a także z jej otoczeniem (z pominięciem otoczenia regulacyjnego) przedstawiono na rysunku 1. Oprócz systemu energetycznego, obejmującego działalności polegające na pozyskiwaniu, transformowaniu oraz transportowaniu energii, w ramach schematu wyróżniono działalność wydobywczą (w tym pozyskiwanie surowców nieenergetycznych), pozostałe działalności produkcyjne, popyt finalny na dobra i usługi oraz zasoby pracy i kapitału. Otoczenie gospodarki reprezentowane jest przez zagranicę i środowisko przyrodnicze. Wśród aktywów środowiska przyrodniczego wykorzystywanych gospodarczo w ramach schematu wyróżniono odnawialne i inne rodzaje źródeł energii pierwotnej, a także surowce nieenergetyczne.

5 Por. np. S. Baumgärtner, Thermodynamic Models, w: J. Proops, P. Safonov (red.), Modelling in Ecological Economics, Edward Elgar, Cheltenham 2004, s. 102-129; H. Thompson, The applied theory of Energy substitution in production, Energy Economics 2006/28/4, s. 410-425; R. Kummel, The Productive Power of Energy and its Taxation, 4th European Congress Economics and Management of Energy in Industry, Porto 2007, http://energiesteuer.net/artikel/ pdf_artikel/portotalk.pdf; stan na 15.09.2015 r.; A. Plourde, D.L. Ryan, Empirical modelling of energy demand, w: J. Evans, L.C. Hunt (red.), International Handbook on Economics of Energy, Edward Edgar, 2009, s. 112-143.

6 J.P. Bruce, H. Lee, E.F. Haites (red.), Climate Change 1995. Economic and Social Dimensions of Climate Change, Cambridge University Press, 1996, s. 280. 
RYSUNEK 1: Obieg energii i system energetyczny jako element gospodarki narodowej

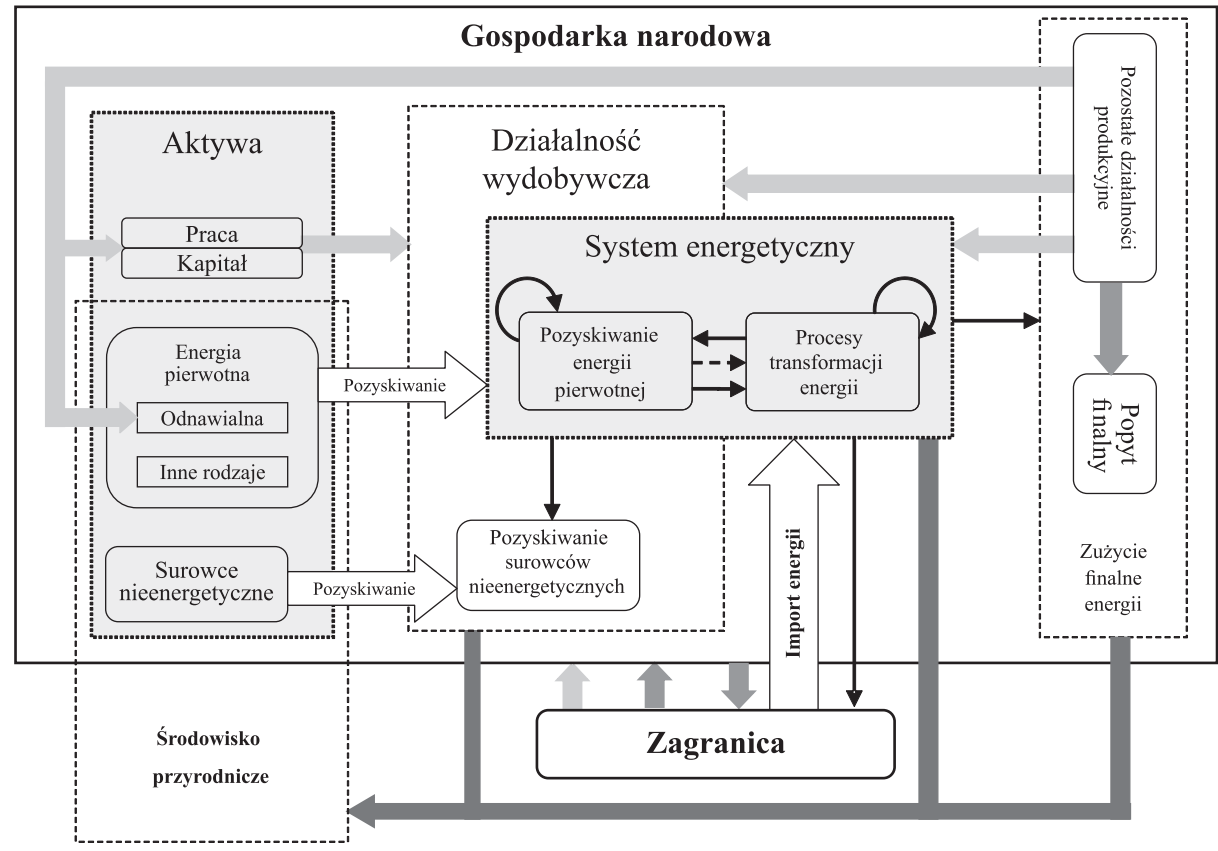

Legenda:

$\begin{aligned} & \longrightarrow \text { przepływy energii finalnej } \\ & \text { finalne przepływy } \\ & \text { nieenergetyczne }\end{aligned}$

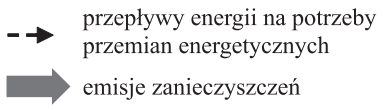

pośrednie przepływy nieenergetyczne

Źr ó d ło: opracowanie własne.

Energię pierwotną pozyskuje się głównie z innych źródeł niż odnawialne, tj. w postaci węgla, gazu ziemnego, ropy naftowej i materiałów rozszczepialnych. Coraz większy udział mają jednak źródła odnawialne, w formie biomasy czy odpadów, oraz uznawane za niewyczerpywalne, takie jak energia wody, słońca, wiatru czy energia geotermalna. Energia pierwotna jest wykorzystywana bezpośrednio do zaspokajania potrzeb energetycznych gospodarki lub zamieniana w procesach transformacji w energię wtórną (pochodną), w postaci prądu elektrycznego, ciepła oraz paliw, głównie płynnych i gazowych.

Jak wynika z rysunku 1, celem systemu energetycznego jest dostarczenie energii w odpowiedniej ilości i formie końcowym (finalnym) użytkownikom energii. Zalicza się do nich zarówno odbiorców finalnych (w rozumieniu rachunków narodowych), jak i te działalności producentów, które nie mają charakteru usługi 
energetycznej (nie są zaliczane do systemu energetycznego). Choć energia pierwotna w pewnych formach może być i bywa wykorzystywana bezpośrednio przez odbiorców finalnych energii (zwykle po odpowiednim przystosowaniu), to jednak transformacja energii pierwotnej do postaci pochodnej jest centralnym komponentem systemów energetycznych. Transformacja odbywa się w ramach różnorodnych procesów technologicznych, które można opisać za pomocą określonych zmiennych i parametrów technicznych, takich jak: zainstalowane moce wytwórcze, sprawność procesu przemiany energii, efektywna liczba godzin pracy instalacji, limity emisji, jednostkowe nakłady inwestycyjne, a także koszty organizacji i zarządzania i koszty likwidacji technologii wyrażone w jednostkach hybrydowych ${ }^{7}$.

W kontekście obiegu energii trzeba również wspomnieć o powiązaniach gospodarki z jej otoczeniem w postaci zagranicy i środowiska przyrodniczego. W niniejszym opracowaniu będziemy abstrahować od tych powiązań, gdyż nie wpływają one zasadniczo na sposób konstrukcji modeli energetycznych. Należy jednak odnotować dwie istotne kwestie, związane z powiązaniami systemu energetycznego $\mathrm{z}$ tak rozumianym otoczeniem gospodarki. Po pierwsze, udział importu energii w zapotrzebowaniu krajowym na energię jest ważnym wskaźnikiem bezpieczeństwa energetycznego gospodarki. Po drugie, wydobycie i przetwarzanie energii z paliw kopalnych przez system energetyczny stanowi podstawowy czynnik silnego, negatywnego oddziaływania gospodarki na środowisko. Dlatego analizy systemu energetycznego są często punktem wyjścia do analiz powiązań gospodarki i środowiska.

\section{Zasady konstrukcji modeli energetycznych}

\subsection{Bloki modelu}

Sprzężenia zwrotne występujące pomiędzy systemem energetycznym a pozostałymi elementami gospodarki powodują, że konstruując modele energetyczne, nie można abstrahować od powiązań tego sektora z resztą gospodarki. Dlatego

\footnotetext{
G. Klima, D. Poznańska (red.), Model optymalnego miksu energetycznego dla Polski do roku 2060, Departament Analiz Strategicznych. Kancelaria Prezesa Rady Ministrów, Warszawa 2013, s. 10-20; M. Pluta i in., Wyniki wstępnych badań nad dtugookresowym rozwojem krajowego system wytwarzania energii elektrycznej w Polsce, Polityka Energetyczna 2012/15/4, s. 91-92; P.J. Deane i in., Soft-linking of a power systems model to an energy systems model, Energy 2012/42/1, s. 308; E.G.R. Davies, S.P. Simonovic, Water resources Research Report. Energy sector for the integrated system dynamics model for analyzing behavior of the social-economicclimatic model, Department of Civil and Environmental Engineering The University of Western Ontario, London 2009, Załącznik 1.
} 
konstrukcja modeli energetycznych powinna uwzględniać dwa bloki: blok energetyczny, przedstawiający zależności wewnątrz systemu energetycznego, i blok ekonomiczny, charakteryzujący pozostałe elementy gospodarki (zob. rysunek 2). Przy takim rozróżnieniu blok energetyczny energii reprezentuje wyłącznie stronę podażową rynku energii, a blok ekonomiczny - otoczenie gospodarcze, w którym funkcjonuje system energetyczny, włącznie ze stroną popytową rynku energii.

RYSUNEK 2: Model energetyczny i jego najważniejsze zmienne (idea modeli energetycznych)

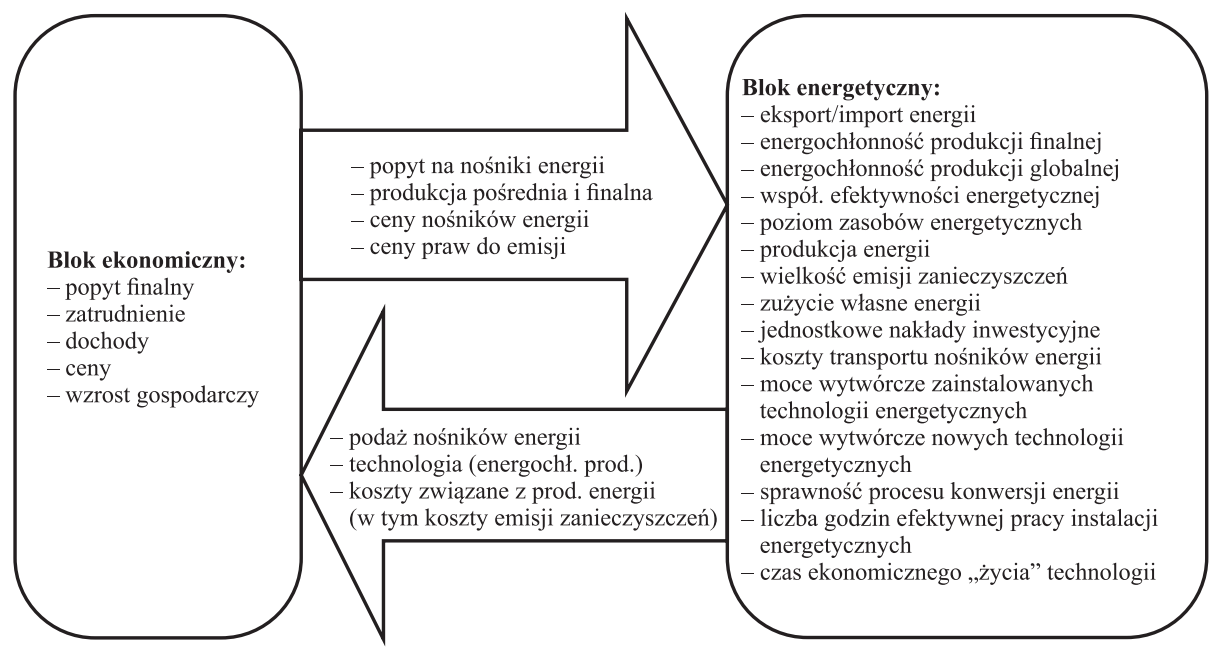

Źródło: opracowanie własne.

Popyt na energię finalną wynika przede wszystkim z działalności otoczenia systemu energetycznego. Rynek energii, rozumiany jako mechanizmy kształtujące ceny i w rezultacie decydujące o skali popytu oraz o opłacalności produkcji w ramach procesów energetycznych, pozostaje częścią bloku ekonomicznego.

W ramach modelu oba bloki - energetyczny i ekonomiczny - powinny być połączone sprzężeniami zwrotnymi i traktowane „równoprawnie”. Rozumiemy przez to pełne odzwierciedlenie interakcji między systemem energetycznym i jego otoczeniem. Aby to było możliwe, oba bloki powinny charakteryzować się zbliżonym stopniem szczegółowości, adekwatnym do charakteru problemów, które mają być za ich pomocą rozwiązane. Praktyka pokazuje, że ten, wydawałoby się oczywisty, postulat nie jest prosty w realizacji, o czym piszemy w punkcie 3.3.

W początkowych etapach rozwoju modeli energetycznych sprzężenia zwrotne pomiędzy blokiem ekonomicznym i energetycznym nie odgrywały 
zasadniczej roli - były marginalizowane lub przedstawiane na bardzo wysokim poziomie ogólności. Wynikało to z faktu, że konstrukcją modeli energetycznych zajmowały się wówczas jednodyscyplinowe zespoły badawcze, złożone z inżynierów albo ekonomistów. Dlatego skupiały się one bądź to na procesach pozyskiwania i przetwarzania energii (podaży energii) w kontekście optymalizacji kosztów wytwarzania (inżynierowie - eksperci od energetyki), bądź też na wpływie ograniczeń podaży energii na gospodarkę (ekonomiści). W rezultacie można mówić o ukształtowaniu się dwóch podejść do budowy modeli energetycznych: podejścia zorientowanego na procesy (podejście inżynierskie), charakterystycznego dla modeli budowanych przez zespoły specjalistów od energetyki, i podejścia ekonomicznego, wywodzącego się z tradycji budowy modeli gospodarek narodowych ${ }^{8}$.

Istotnym aspektem wpływającym na funkcjonowanie systemu energetycznego, a tym samym na konstrukcję modeli energetycznych, którego nie uwzględniono wprost w ramach rysunków 1 i 2 , są możliwości substytucji pomiędzy różnymi rodzajami energii, a także różnymi technikami jej wytwarzania i wykorzystania. Leżą one zarówno po stronie producentów, jak i odbiorców końcowych energii. W przypadku producentów możliwości te dotyczą technik wytwarzania określonych rodzajów energii, a w przypadku odbiorców końcowych wykorzystania różnych rodzajów energii do zaspokajania określonych potrzeb. Ujmując rzecz bardzo szeroko, można stwierdzić, że w obu przypadkach możliwości te zależą od:

- regionu (kraju, kontynentu, świata),

- dostępnych w danym czasie technik wytwarzania i wykorzystania energii (stan wiedzy na poziomie użytkowym),

- rodzaju odbiorcy (gospodarstwa domowe, przedsiębiorstwa),

- istniejącej infrastruktury (po stronie producentów i odbiorców),

- kapitału (określa możliwości inwestowania w zmiany infrastruktury).

Ważnym czynnikiem wpływającym na możliwości substytucji jest również trwający w czasie postęp wiedzy, którego rezultatem są nowe techniki wytwa-

8 Por. np. N.M.J.P. van Beeck, Classification of Energy Models, FEW Research Memorandum. Operations research 1999/777, Tilburg, s. 11-12; E. Peterson i in., Panel discussion on the future of national energy modelling, w: W.T. Ziemba, S.L. Schwarz, Energy Policy Modeling: United States and Canadian Experiences: Volume I Specialized Energy Policy Models, Springer Science \& Business Media, 2012, s. 250; W. Łyżwa, B. Olek, M. Wierzbowski, Optymalizacja krajowego miksu energetycznego w kontekście polityki energetycznej, Rynek Energii 2014/5, s. 3; J.W. Hall, R. Nicholls, M. Tran, A. Hickford, The future of national infrastructure: A system-of-systems approach, Cambridge University Press, 2016, Załącznik B. 
rzania i wykorzystania energii, stanowiące alternatywę dla tych, które wcześniej były powszechnie stosowane. Substytucja może być też wymuszona w związku z zagrożeniami, które niesie ze sobą wykorzystanie niektórych rodzajów energii. Przykładem tego typu zagrożeń jest wyczerpywanie źródeł energii nieodnawialnej, zagrożenia dla środowiska wynikające z emisji gazów cieplarnianych, skażeniami radioaktywnymi itp.

W rozważaniach nad możliwościami substytucji w związku z wytwarzaniem i wykorzystaniem energii nie można zapomnieć, że energia jest dobrem rynkowym. W tym kontekście bezpośrednią przyczyną substytucji są zwykle zmiany w opłacalności wytwarzania (w przypadku producentów) i wykorzystania (w przypadku odbiorów końcowych) określonych rodzajów energii. Generalnie rzecz ujmując, o opłacalności decydują relacje cen rynkowych, choć trzeba pamiętać, że ze względu na strategiczne znaczenie energii dla gospodarki relacje te mogą pozostawać pod wpływem interwencji rządowych.

\subsection{Podejścia do budowy modeli energetycznych}

Nurt ekonomiczny budowy modeli energetycznych bazuje na tradycjach modelowania ekonomicznego. Kluczową rolę w funkcjonowaniu gospodarki odgrywają w nim siły popytu i podaży. W wyniku ich wzajemnego oddziaływania w ramach poszczególnych rynków ustalane są ceny rynkowe. Ekonomiści od zawsze spierają się, która z tych sił jest wiodąca, i tym samym powinna stanowić podstawę modelowania gospodarki. Na obecnym etapie rozwoju ekonomii wyróżnia się zwykle dwie dominujące teorie - neoklasyczną i neokeynesowską9

Podejście neoklasyczne wykorzystuje koncepcję równowagi ogólnej (general equilibrium) wyrażonej jako stan gospodarki, której wszystkie rynki znajdują się w stanie równowagi między rozmiarami produkcji a popytem, za przyczyną doskonale elastycznych cen na wszystkich rynkach (produktów, pracy, kapitałowym i pieniężnym). Stało się ono podstawą do konstrukcji modeli CGE (computable general equilibrium), które od dłuższego czasu dominują w badaniach poświęconych modelowaniu gospodarek (zarówno dla ujęć regionalnych, krajowych, grup krajów i w badaniach gospodarki światowej).

W podejściu neokeynesowskim głównym przedmiotem zainteresowań są czynniki wpływające na agregatowy popyt. Jednocześnie podaje się w wątpliwość

9 Zob. np. C. Kemfert, T. Truong, Energy-economy-environment modeling: a survey, w: J. Evans, L.C. Hunt (red.), International Handbook on Economics of Energy, Edward Edgar, 2009, s. 367-369; L. Próchnicki, Nowa szkoła Keynesowska - teoretyczne i polityczne implikacje, Studia i Prace WNEiZ 2011/16, s. 67-69. 
niektóre z założeń neoklasycznych, w szczególności te dotyczące możliwości osiaggania stanu równowagi rynkowej z uwagi na sztywność cen w dó $1^{10}$.

Niezależnie od tego, na jakich złożeniach teoretycznych opiera się konstrukcja modeli ekonomicznych - neoklasycznych i neokeynesowskich - podstawowym źródłem danych do budowy ich wersji operacyjnych (empirycznych) są rachunki narodowe, a w szczególności tablice przepływów międzygałęziowych i ich rozszerzenia w postaci macierzy SAM (social accounting matrices) ${ }^{11}$. W przypadku gdy celem modelowania jest dołączenie do modelu ekonomicznego elementów charakteryzujących sektor energetyczny (dołączenie bloku energetycznego), dane te mogą być jednak niewystarczające z co najmniej dwóch powodów. Pierwszym jest niewystarczająca rozdzielczość danych w rachunkach narodowych, przejawiająca się brakiem lub słabą dezagregacją rodzajów działalności związanych z dostarczaniem energii (lub jej rozproszeniem pomiędzy różne inne rodzaje działalności), a także brakiem wyodrębnienia charakteru zużycia energii wśród jej odbiorców końcowych. Po drugie, dane pochodzące z rachunków narodowych przedstawione są $\mathrm{w}$ ujęciu wartościowym, co w praktyce uniemożliwia sporządzanie na ich podstawie bilansu energii ujmowanego w jednostkach naturalnych lub jednostkach energii będącego ważnym elementem w procesie podejmowania decyzji gospodarczych ${ }^{12}$.

Nurt inżynierski modelowania energetycznego charakteryzuje się budową modeli skoncentrowanych na stronie podażowej rynku energii. Celem ich konstrukcji jest zwykle optymalizacja funkcjonowania systemu energetycznego. Optymalizacja ta polega na poszukiwaniu minimum funkcji celu wyrażanej jako zdyskontowany koszt działania tego systemu ${ }^{13}$. Charakterystyczna dla tego typu modeli jest duża szczegółowość w zakresie wyodrębnienia nośników energii i opisu procesów jej przetwarzania. Bazują one na danych charakteryzujących dostępne techniki pozyskiwana i przetwarzania energii. Właśnie dlatego modele tego typu są określane jako modele energetyczne zorientowane na procesy ${ }^{14}$.

10 C. Kemfert, T. Truong, op. cit., s. 368.

11 Por. np. R. Miller, P. Blair, op. cit., s. 499-542; M. Plich, Budowa i zastosowanie wielosektorowych modeli ekologicznych, Wydawnictwo Uniwersytetu Łódzkiego, Łódź 2002, s. 56-57.

12 Por. M. Plich, J. Skrzypek, Trendy energochłonności sektorów polskiej gospodarki w latach 1996-2012, Wiadomości Statystyczne 2016/7/2016, s. 16-38.

13 Por. W. Suwala, Problemy ekonomiczne modelowania systemów paliwowo-energetycznych, Polityka Energetyczna 2010/13/2, s. 435-448; W. Suwala, Typowe elementy i modele systemów paliwowo-energetycznych, Zeszyty Naukowe Instytutu Gospodarki Surowcami Mineralnymi i Energii Polskiej Akademii Nauk 2009/76/2009.

14 N.M.J.P. van Beeck, Classification ..., s. 10-12; C. Bataille, A. Lorna, op. cit., s. 257-259; A. Herbst, F. Toro, F. Reitze, E. Jochem, Introduction to Energy Systems Modelling, 
Dane niezbędne do ich budowy pochodzą ze źródeł normatywnych i statystycznych o wysokim stopniu szczegółowości, wyrażających energię w jednostkach naturalnych lub w jednostkach energii.

Podstawowym wejściem do modeli inżynierskich jest zapotrzebowanie na energię według rodzajów. Techniki wytwarzania energii są charakteryzowane za pomocą parametrów technicznych i ograniczeń w postaci wielkości zdolności produkcyjnych. Możliwości substytucji jednego rodzaju energii za pomocą innych sprowadzają się do zastosowania alternatywnych technik wytwarzania. Techniki charakteryzują się różną opłacalnością, wynikającą z relacji cen czynników produkcji i cen energii. Maksymalizacja opłacalności jest typowym kryterium wyboru w tego typu modelach.

Skutkiem koncentracji na procesach energetycznych jest marginalizowanie lub wręcz ignorowanie wpływu otoczenia na funkcjonowanie systemu energetycznego, w tym zwłaszcza czynników popytowych. W modelach inżynierskich bywa on sprowadzany do zestawu egzogenicznych założeń dotyczących zmiennych makroekonomicznych. Egzogeniczny popyt uniemożliwia przedstawienie interakcji systemu energetycznego z jego otoczeniem, co ogranicza możliwości wykorzystania modeli inżynierskich do wspomagania procesów decyzyjnych na szczeblu makroekonomicznym.

Konfrontując przedstawione powyżej podstawowe cechy podejścia ekonomicznego i inżynierskiego z założeniami modeli energetycznych, przedstawionymi schematycznie na rysunku 2 , dochodzimy do wniosku, że modele te stanowiłyby dobrą podstawę do budowy odpowiednich bloków w modelach energetycznych, tj. bloku ekonomicznego i bloku energetycznego. Okazuje się jednak, że połączenie tak skonstruowanych bloków nie jest sprawą prostą.

\subsection{Problemy integracji bloków}

Podejście ekonomiczne i inżynierskie w odmienny sposób przedstawiają rzeczywistość gospodarczą. W przypadku ujęcia inżynierskiego jest to przedstawienie fragmentaryczne, ale bardzo szczegółowe, natomiast ujęcie ekonomiczne, choć ma charakter kompleksowy, to przedstawia rzeczywistość na dużo wyższym poziomie ogólności. Można stwierdzić, że każde z nich jest najlepsze „w swojej klasie”, bo uwzględnia w pełni potrzeby i najlepsze możliwości, co do użycia właściwych danych i metod modelowania każdego z bloków. Problem pojawia się wówczas,

Swiss Society of Economics and Statistics 2012/148/2, s. 111-113; Peterson E. i in., op. cit., s. 249-250. 
gdy próbuje się dokonać połączenia tak zbudowanych bloków, tj. uwzględnić interakcje wynikające z powiązań systemu energetycznego z innymi rodzajami działalności gospodarczych. Wówczas odmienność przyjętych zasad modelowania staje na drodze do integracji modeli budowanych według tych odmiennych tradycji.

Próby połączenia modeli wywodzących się z tradycji ekonomicznej i inżynierskiej napotykają szereg trudności o różnej naturze metodologicznej (odmienne typy matematyczne modeli, a tym samym i metody ich rozwiązywania/ wykorzystania), statystycznej (różnice w poziomach szczegółowości obu podejść i charakterze danych statystycznych użytych do ich konstrukcji) i informatycznej (odmienne narzędzia implementacji komputerowej obu typów modeli).

Z uwagi na interakcje występujące pomiędzy systemem energetycznym i innymi działalnościami, kluczową dla budowy modelu energetycznego kwestią są możliwości połączenia obu jego bloków. Możliwości te zależą od stopnia szczegółowości i sposobu pomiaru danych, na których bazuje konstrukcja każdego z nich.

W przypadku bloku ekonomicznego dane przedstawione są w ujęciu wartościowym i mogą być charakteryzowane na poziomie makroekonomicznym lub sektorowym. Granice jego szczegółowości określa poziom dezagregacji tablic input-output dostępnych dla danej gospodarki. Dane w bloku energetycznym wyrażone są zwykle w jednostkach naturalnych, a podaż energii charakteryzowana jest w nim zwykle jako suma energii z konkretnych procesów (technologii). Wynika stąd, że połączenie obu bloków w ramach jednego modelu wymaga rozwiązania dwóch istotnych problemów. Pierwszy problem wynika z odmienności stopnia szczegółowości klasyfikacji używanych w konstrukcji obu bloków, w tym zastosowanych w nich klasyfikacji nośników energii. Drugi zaś związany jest z transformacją danych o popycie na energię z ujęcia wartościowego na ilościowe, a w przypadku podaży - z ujęcia ilościowego na wartościowe.

Warunkiem połączenia bloków jest harmonizacja wykorzystywanych w nich danych, (czyli dostosowanie klasyfikacji i sposobu pomiaru) lub zastosowanie odpowiedniego sprzężenia zapewniającego stosowne przejścia (połączenia). W szczególności dotyczy to zmiennych bloku ekonomicznego takich jak popyt na nośniki energii i ceny energii, które zasilają blok energetyczny (por. rysunek 2).

Jeśli priorytetem podczas budowy modelu energetycznego jest osiąnnięcie szczegółowości na poziomie wyznaczonym w ramach bloku energetycznego, to należy skorzystać z maksymalnej dostępnej dezagregacji danych ekonomicznych. W praktyce, ograniczeniem poziomu szczegółowości danych bloku ekonomicznego jest poziom szczegółowości tablic przepływów międzygałęziowych. Harmonizacji danych w ujęciu ilościowym pochodzących z bloku energetycznego $\mathrm{z}$ danymi bloku ekonomicznego, przedstawionymi w ujęciu wartościowym można 
dokonać z pomocą bilansów energetycznych sporządzanych dla sektorów gospodarki ${ }^{15}$. Harmonizacja i integracja danych o energii przedstawionych w ujęciu fizycznym $\mathrm{z}$ danymi ekonomicznymi, przedstawionymi w ujęciu wartościowym jest jednak poważnym wyzwaniem konceptualnym i empirycznym ${ }^{16}$.

Odrębnym zagadnieniem ograniczającym możliwość uwzględnienia interakcji obu bloków jest znaczący wzrost poziomu złożoności takich modeli, implikujący coraz wyższy poziom trudności ich obsługi na wszystkich etapach prac, począwszy od budowy i wdrażania, po wykorzystanie modelu. W rezultacie modele integrujące blok ekonomiczny z blokiem energetycznym są dużo kosztowniejsze i wymagają od użytkowników wyższych umiejętności.

\section{Modele wielosektorowe w klasyfikacjach modeli energetycznych}

W literaturze można znaleźć wiele prób usystematyzowania modeli energetycznych ${ }^{17}$. Bliższa analiza pokazuje, że poza niewatpliwymi podobieństwami proponowane klasyfikacje różnią się pod względem liczby wyróżnionych kryteriów, stosowanych przekrojów, a w przypadku zbliżonych lub tożsamych kryteriów klasyfikacyjnych również typami wyróżnionych modeli. Skoncentrujmy się na klasyfikacji zaproponowanej w opracowaniu van Beeck (1999) ${ }^{18}$, na które powołują się również inni autorzy z uwagi na zastosowanie w nim stosunkowo szerokiego spektrum kryteriów klasyfikacyjnych. Choć od ukazania się tego opracowania minęło już kilkanaście lat ${ }^{19}$, to jednak w kwestiach klasyfikacji niewiele się od tej pory zmieniło, czego świadectwem są nowsze publikacje odwołujące się do opracowania van Beeck ${ }^{20}$.

15 Zob. Gospodarka paliwowo-energetyczna, Główny Urząd Statystyczny (GUS), Warszawa 1997 i n.; M. Plich, J. Skrzypek, Trendy...

16 C. Kemfert, T. Truong, op. cit., s. 370-371; C.W. Frei, P.-A. Haldi, G. Sarlos, Dynamic formulation of a top-down and bottom-up merging energy policy model, Energy Policy 2003/31 (2003), s. 1030.

17 Najnowsza - Hall i Buckley (2016) - skoncentrowana jest wprawdzie na modelowaniu systemu energetycznego w Wielkiej Brytanii, ale zawiera również treści o charakterze ogólnym, niezwiązane ze specyfiką gospodarki tego kraju (zob. L.M.H. Hall, A.R. Buckley, A review of energy systems models in the UK: Prevalent usage and categorization, Applied Energy 2016/169, s. 607-628).

18 N.M.J.P. van Beeck, Classification...

19 Ta klasyfikacja (z niewielkimi zmianami) przedstawiona jest również w pracy doktorskiej N.M.J.P. van Beeck, A new decision support method for local energy planning in developing countries, CentER, Center for Economic Research, Tilburg 2003.

$20 \mathrm{~Np}$. J. Timmerman, L. Vandevelde, G. Van Eetvelde, Towards low carbon business park energy systems: Classification of techno-economic energy models, Energy 2014/75, s. 68-80; L. Benichou, S. Mayr, Rogeaulito: A World Energy Scenario ModelingTool for Transparent Energy System- 
Na podstawie przeglądu obejmującego 11 pozycji literatury van Beeck formułuje 9 kryteriów, przyporządkowując im różne typy modeli energetycznych (zob. tabela 1). Okazuje się jednak, że z punktu widzenia zasad typologii ten wykaz nie jest doskonały, bo zestaw kryteriów jest niepełny, niektóre spośród uwzględnionych kryteriów nie są rozłączne, a lista typów modeli w przypadku niektórych kryteriów nie jest wyczerpująca. Te mankamenty dostrzega sama autorka, uzasadniając je wysokim stopniem komplikacji modeli energetycznych ${ }^{21}$.

TABELA 1: Kryteria i klasyfikacja modeli energetycznych wedlug van Beeck (1999)

\begin{tabular}{|l|l|}
\hline \multicolumn{1}{|c|}{ Kryterium } & \multicolumn{1}{c|}{ Klasyfikacja i uwagi } \\
\hline $\begin{array}{l}\text { Cele (ogólne } \\
\text { i szczegółowe) }\end{array}$ & $\begin{array}{l}\text { Cele ogólne: prognozownie; analizy scenariuszowe; backcasting. } \\
\text { Cele szczegółowe: modele popytu; modele podaży; badanie oddziaływania } \\
\text { (ang. impact models); modele wyceny (ang. appraisal models). }\end{array}$ \\
\hline $\begin{array}{l}\text { Struktura modelu } \\
\text { (założenia } \\
\text { modelu) }\end{array}$ & $\begin{array}{l}\text { Założenia wewnętrzne: stopień endogenizacji modelu; szczegółowość } \\
\text { opisu sektorów nieenergetycznych, odbiorców finalnych energii, technologii } \\
\text { wytwarzania energii. } \\
\text { Założenia zewnętrzne: wzrost populacji, wzrost gospodarczy, popyt na ener- } \\
\text { gię, podaż energii, elastyczności cenowe i dochodowe, system podatkowy } \\
\text { i recykling podatkowy. }\end{array}$ \\
\hline $\begin{array}{l}\text { Podejście } \\
\text { analityczne }\end{array}$ & $\begin{array}{l}\text { Top-Down (od ogółu do szczegółu); } \\
\text { Bottom-Up (od szczegółu do ogółu); } \\
\text { Podejście top-down skojarzone jest z konstrukcją bloku ekonomicznego, } \\
\text { a bottom-up - energetycznego. }\end{array}$ \\
\hline $\begin{array}{l}\text { Metody } \\
\text { modelowania }\end{array}$ & $\begin{array}{l}\text { Modele: ekonometryczne; makroekonomiczne; równowagi; optymalizacyjne; } \\
\text { symulacyjne; arkuszy kalkulacyjnych; backcasting; wielokryteriowe. }\end{array}$ \\
\hline $\begin{array}{l}\text { Podejście } \\
\text { matematyczne }\end{array}$ & $\begin{array}{l}\text { Programowanie: liniowe; mieszane całkowitoliczbowe; dynamiczne. } \\
\text { Autorka zauważa, że są to jedynie przykłady zwykle używanych metod } \\
\text { i nadmienia, że nie uwzględnia m.in. nowych metod w postaci technik wie- } \\
\text { lokryteriowych i zbiorów rozmytych. }\end{array}$ \\
\hline $\begin{array}{l}\text { Zasięg } \\
\text { geograficzny }\end{array}$ & Globalny, regionalny, narodowy, lokalny, projekt (project) \\
\hline $\begin{array}{l}\text { Zasięg } \\
\text { sektorowy }\end{array}$ & $\begin{array}{l}\text { Pojedyncze sektory; wiele sektorów. } \\
\text { To kryterium nie jest rozłączne z kryterium struktury modelu, gdzie wśród } \\
\text { założeń wewnętrznych wyróżniono m.in. szczegółowość opisu sektorów. }\end{array}$ \\
\hline
\end{tabular}

Thinking, Frontiers in Energy Research 2014, doi: http://dx.doi.org/10.3389/fenrg.2013.00013;

F. Urban, R.M.J. Benders, H.C. Moll, Modelling energy systems for developing countries, Energy Policy 2007/35 (2007), s. 3473-3482; T. Nakata, Energy-economic models and the environment, Progress in Energy and Combustion Science 2004/30, s. 417-475 i in.

21 Inni autorzy analizujący spotykane w literaturze klasyfikacje (np. N. Neshat, M. Reza Amin-Naseri, F. Danesh, Energy models: methods and characteristics, Journal of Energy in Southern Africa 2014/25/4, s. 101-111) zwracają również uwagę na trudności związane z kategoryzacją modeli energetycznych. 


\begin{tabular}{|l|l|}
\hline \multicolumn{1}{|c|}{ Kryterium } & \multicolumn{1}{c|}{ Klasyfikacja i uwagi } \\
\hline $\begin{array}{l}\text { Horyzont } \\
\text { czasowy }\end{array}$ & Okres: krótki; średni; długi. \\
\hline $\begin{array}{l}\text { Wymagania } \\
\text { dotyczące } \\
\text { danych }\end{array}$ & $\begin{array}{l}\text { mierzalne; wyrażone ilościowo, wartościowo; niemierzalne (jakościowe); } \\
\text { zagregowane, zdezagregowane. } \\
\text { Zastosowanie danych pochodzących z różnych źródeł i stosujących odmienne } \\
\text { klasyfikacje rodzi konieczność ich harmonizacji, zwłaszcza w przypadku } \\
\text { budowania modeli o zasięgu międzynarodowym (Kemfert, Truong 2009). }\end{array}$ \\
\hline
\end{tabular}

Ź r ó d ł o: opracowanie własne na podstawie N.M.J.P. van Beeck, Classification of Energy Models, FEW Research Memorandum. Operations research 1999/777, Tilburg.

Analiza informacji zawartych w tabeli 1 prowadzi do wniosku, że większość zastosowanych kryteriów i przypisane im typy modeli nie są specyficzne dla modeli energetycznych, ale mają ogólny charakter. Są dobrze znane, bo odnoszą się do wszelkich modeli matematycznych lub ekonomicznych. Nie eksponują więc cech charakterystycznych dla modeli energetycznych, które wynikają ze współistnienia $\mathrm{w}$ ramach jednego modelu dwóch ściśle powiązanych ze sobą bloków - ekonomicznego i energetycznego - często wykorzystujących odmienne metody matematyczne, klasyfikacje rodzaju działalności i sposoby pomiaru zmiennych ${ }^{22}$.

Kryteria, które naszym zdaniem odnoszą się bezpośrednio do własności modeli energetycznych, to:

- sposób połączenia bloków,

- rodzaj użytych danych,

- podejście analityczne.

$\mathrm{Z}$ tego punktu widzenia na uwagę zasługuje kryterium określone jako podejście analityczne i (w pewnym stopniu) metody modelowania oraz zasięg sektorowy, które nawiązują do proponowanego przez nas ujęcia.

22 Do podobnych wniosków dochodzimy, analizując wiele innych opracowań dotyczących klasyfikacji modeli energetycznych, w tym również opracowania polskich autorów, np. W. Lyżwa, B. Olek, M. Wierzbowski, Optymalizacja...; R. Szczerbowski, Modelowanie systemów energetycznych - charakterystyka wybranych modeli, Polityka Energetyczna 2014/17/3, s. 147-156; J. Kamiński, P. Kaszyński, Wybrane problemy implementacji zapotrzebowania na moc w matematycznych modelach systemów elektroenergetycznych, Polityka Energetyczna 2011/14/2, s. 155-166; M. Kudełko, Znaczenie analizy systemowej w prognozowaniu rozwoju sektorów paliwowo-energetycznych, Polityka Energetyczna 2005/8, zeszyt specjalny, s. 245-260; B. Jankowski, Modelowanie rozwoju krajowego systemu energetycznego z uwzględnieniem wymagań stabilizacji i redukcji emisji dwutlenku węgla w Polsce, IPPT PAN 1997, praca doktorska. 
Sposób połaczenia bloków jako kryterium różnicujące modele energetyczne wymieniane jest w licznych publikacjach ${ }^{23}$. W tym kontekście wyróżnia się dwa rodzaje połączeń: mocne (ang. hard link), w którym wymiana rozwiązań pomiędzy blokami jest zapewniona automatycznie poprzez zastosowane specjalnego oprogramowania, oraz słabe (ang. soft link), gdy wymiana rozwiązań nie odbywa się w warunkach automatyzacji (lecz w sposób „ręczny”, jak określa to Herbst ${ }^{24}$ ).

Przypomnijmy, że celem połączenia bloków modelu energetycznego jest uwzględnienie interakcji sektora energetycznego z resztą gospodarki. Jeśli rozważać bloki modelu energetycznego jako dwa oddzielne modele, wyrosłe z różnych tradycji (ekonomicznej i inżynierskiej), to powstałą w ten sposób konstrukcję można określić jako model hybrydowy. Modele hybrydowe pozwalają zatem uchwycić zarówno zróżnicowanie technologii produkcji energii, jak i zapewnić wewnętrzną zgodność przyjętych założeń makroekonomicznych. W literaturze często ogranicza się pojęcie modeli hybrydowych do sytuacji, gdy bloki modelu energetycznego są sprzężone mocnymi połączeniami ${ }^{25}$.

Rodzaj danych użytych do budowy modelu energetycznego ma kluczowe znaczenie dla możliwości połączenia jego bloków. Wychodząc z założenia, że konstrukcja bloku wykorzystania energii jest oparta na tradycji inżynierskiej, budując blok ekonomiczny należy użyć danych o jak najwyższym stopniu szczegółowości. W przypadku gospodarki są to dane zawarte w tablicach input-output. Ich użycie implikuje konstrukcję modelu zaliczanego do klasy wielosektorowych modeli gospodarki. Charakteryzując zasięg sektorowy modeli energetycznych, van Beeck ${ }^{26}$, a także inni autorzy ${ }^{27}$ wspominają o modelach wielosektorowych. $\mathrm{Z}$ drugiej strony, van Beeck, podążając za literaturą, wśród metod modelowania wyróżnia modele makroekonomiczne, wiążąc je wprost z wykorzystaniem tablic

${ }^{23}$ Np. N. Bauer, O. Edenhofer, S. Kypreos, Linking energy system and macroeconomic growth models, Computational Management Science 2008/5/1, s. 95-117; C. Böhringer, Combining Bottom-Up and Top-Down, Energy Economics 2008/30/2, s. 574-596; C. Kemfert, T. Truong, op. cit.; A. Herbst, F. Toro, F. Reitze, E. Jochem, op. cit.

${ }^{24}$ A. Herbst, F. Toro, F. Reitze, E. Jochem, op. cit.

25 Np. C. Böhringer, The synthesis of bottom-up and top-down in energy policy modelling, Energy Economics 1998/20/3, s. 233-248; C. Böhringer, op. cit.; P.R. Shukla, Review of linked modelling of low-carbon development, mitigation and its full costs and benefits, Mitigation Action Plans \& Scenarios, 2013; V. Bosetti, A. Golub i in., Abatement cost uncertainity and policy instrument selection under a stringent climate policy, w: A. Golub, A. Markandya, Modeling environment - improving technological innovations under uncertainty, Routlege, London and New York 2008, s. 127-157.

26 N.M.J.P. van Beeck, Classification..., s. 13.

27 Np. L.M.H., Hall, A.R. Buckley, op. cit., s. 612-613. 
input-otput. Takie rozumienie modeli makroekonomicznych nie jest odosobnione ${ }^{28}$. Budzi ono dwa następujące zastrzeżenia.

Po pierwsze, określenie model makroekonomiczny odnosi się raczej do charakteru zmiennych endogenicznych używanych w modelu, a nie do konkretnej metody modelowania. Istotą modeli makroekonomicznych jest to, że wszystkie lub prawie wszystkie zmienne endogeniczne są zmiennymi makroekonomicznymi, czyli dotyczącymi całej gospodarki (np. PKB, bezrobocie, stopy procentowe itp.), a nie zmiennymi sektorowymi. Budowanie modelu makroekonomicznego nie jest równoznaczne $\mathrm{z}$ wykorzystaniem konkretnej metody modelowania ${ }^{29}$.

Po drugie, wykorzystanie tablic input-output w modelowaniu zwykle prowadzi do budowy tzw. modeli wielosektorowych, w odróżnieniu od modeli makroekonomicznych. W modelach wielosektorowych zmienne endogeniczne, mające charakter makroekonomiczny, są zwykle wyznaczane za pomocą odpowiednich zmiennych na poziomie sektorów gospodarki (zmiennych sektorowych), tj. wedhug zasady bottom-up. Dlatego modeli, które wykorzystują tablice input-output nie należy utożsamiać z modelami makroekonomicznymi.

Przyjrzyjmy się bliżej naturze modeli wielosektorowych. Wśród zmiennych endogenicznych modeli wielosektorowych mogą występować zmienne makroekonomiczne. Niektóre z nich - te, które mają odpowiedniki w zmiennych sektorowych - takie jak produkcja globalna, wartość dodana czy zatrudnienie w całej gospodarce, buduje się przez agregację zmiennych sektorowych. Modele wielosektorowe, w których zmiennymi endogenicznymi są wzajemnie na siebie oddziałujące zmienne sektorowe i makroekonomiczne, i odwołujące się głównie do teorii neokeynesowskiej określa się jako wielosektorowe modele makroekonomiczne (WMM). Oddzielną klasą modeli wielosektorowych są szeroko rozpowszechnione w literaturze modele CGE odwołujące się do teorii neoklasycznej ${ }^{30}$.

28 N. Neshat i in., op. cit., s. 103-104; S. Bhattacharyya, G.R. Timisina, A review of energy system models, International Journal of Energy Sector Management 2010/4/4, s. 4, 6; N.S. Rathore, N.L. Pawnar, Renewable Energy Sources for Susutainable Development, New India Publishing Agency, New Delhi 2007, s. 65.

29 W przypadku modeli matematycznych jako metodę modelowania rozumie się raczej sposób wiązania ze sobą zmiennych i parametrów w liniowe lub nieliniowe równania bądź nierówności, a także metody określania parametrów.

30 M. Plich, Budowa ..., s. 157-158; J.F. Werling, MIDE: a macroeconomic multisectoral model of Spanish economy, Faculty of the Graduate School of The University of Maryland 1992, praca doktorska, http://ma.umd.edu/papers/publishedwork/dissertations/werling.pdf; stan na 20.05.2016 r., s. 64-75. 
Podejście analityczne do budowy bloków modeli energetycznych jest ważnym kryterium klasyfikacyjnym, w ramach którego wyodrębnia się zasadę bottom-up i top-down. W szerokim rozumieniu zasady te oznaczają dwie odmienne strategie badawcze (strategie przetwarzania informacji) w sytuacji, gdy można dokonać dezagregacji obiektu badania na mniejsze składowe. W odniesieniu do modeli matematycznych chodzi o sytuacje, gdy ta sama kategoria (zmienna) może być przedstawiona na różnych poziomach szczegółowości (dezagregacji). Zastosowanie zasady top-down polega na zbudowaniu równania dla zmiennej zagregowanej, która jest następnie - w miarę potrzeb - dezagregowana na zmienne szczegółowe. Stosując zasadę bottom-up, buduje się równania dla wszystkich zmiennych szczegółowych, aby następnie na ich podstawie skonstruować zmienną zagregowaną ${ }^{31}$.

Wszystkie klasyfikacje modeli energetycznych, w tym również omawiana klasyfikacja van Beeck, określają bloki energetyczne jako konstruowane według zasady bottom-up, zaś blokom ekonomicznym przypisują zasadę top-down. W przypadku bloków energetycznych wydaje się to oczywiste z uwagi na wysoki stopień szczegółowości opisu procesów energetycznych w ramach nurtu inżynierskiego. W przypadku bloków ekonomicznych, konstruowanych w oparciu ideę modeli wielosektorowych, możliwe jest natomiast zastosowanie zarówno zasady top-down, jak i bottom-up, na co twórcy klasyfikacji modeli energetycznych nie zwrócili jak dotąd uwagi. Choć zasada top-down jest dużo prostsza i mniej kosztowna w zastosowaniach, to z punktu widzenia jakości odwzorowania zjawisk gospodarczych preferowana powinna być zasada bottom-up. W modelach wielosektorowych reguła ta oznacza, że model wyjaśnia zjawiska ekonomiczne na szczeblu sektorów, a następnie wielkości sektorowe są agregowane do wielkości makroekonomicznych. Tak konstruowane są na przykład modele typu Inforum, zaliczane do grupy WMM, o których wspominamy w kolejnym punkcie.

Konkludując, w klasyfikacjach modeli energetycznych nie przywiązuje się wagi lub traktuje jako oczywisty fakt, że bloki ekonomiczne w ramach modeli energetycznych mogą być przedstawiane w ujęciu wielosektorowym, i że sektory gospodarki mogą być modelowane nie tylko według zasady top-down, ale także bottom-up. Oba wymienione aspekty mają istotny wpływ na możliwości integracji bloków (ekonomicznego i energetycznego) i jakość konstruowanych

31 Van Beeck konkluduje swoje rozważania poświęcone modelom top-down i bottom-up, stwierdzając, iż różnice pomiędzy nimi mogą być ogólnie scharakteryzowane jako różnice pomiędzy modelami zagregowanymi i zdezagregowanymi lub modelami o maksymalnym i minimalnym stopniu endogenizacji zachowań (por. N.M.J.P. van Beeck, $A$ new...). Naszym zdaniem ta konkluzja nie sięga sedna sprawy. 
modeli energetycznych. Wysoki poziom dezagregacji bloku ekonomicznego zbliża go do poziomu szczegółowości bloku energetycznego. Granicę wyznacza dostępność danych o gospodarce, a w praktyce poziom dezagregacji sektorowej tablic input-output i bilansów energetycznych.

\section{Konstrukcja bloku popytu na energię w modelach WMM}

\subsection{Własności modeli WMM}

Wśród modeli wielosektorowych, pominąwszy klasyczne modele input-output i ich rozwinięcia wykorzystujące techniki analizy input-output, wyróżnia się dwie klasy modeli - CGE i WMM. Modele CGE mają znacznie krótsza tradycję, ale od prawie 30 lat dominują w literaturze ekonomicznej. Modele WMM nie są tak często wykorzystywane. Jednym z ważnych aspektów, które się do tego przyczyniają, są stosunkowo wysokie koszty ich budowy, wynikające z konieczności zebrania i opracowania znacznej ilości danych. Dyskusje, które ujęcie jest właściwsze, nie doprowadziły jak dotąd do jednoznacznych konkluzji. Z całą pewnością da się zauważyć tendencję do upodabniania się obu typów modeli, ale podstawowe ich cechy wywodzące się z odmiennych stanowisk osadzonych w teorii ekonomii pozwalają je łatwo odróżnić. Modele CGE są mocno osadzone w teorii neoklasycznej i zwykle bazują na jej fundamentalnych założeniach o istnieniu konkurencji doskonałej oraz racjonalnych zachowaniach i perfekcyjnych przewidywaniach uczestników rynku. Modele WMM opierają się mocno na danych empirycznych, co znajduje odzwierciedlenie w parametrach określanych na podstawie danych historycznych (szeregi czasowe lub przekrojowe), przy użyciu metod ekonometrycznych.

Najbardziej znane na świecie ośrodki, w których rozwija się modele WMM, to Cambridge Econometrics w Wielkiej Brytanii (www.camecon.com), Inforum w USA (www.inforum. umd.edu) i GWS w Niemczech (www.gws-os.com). Modele tam tworzone bazują na podobnych zasadach, które przedstawimy w ujęciu zaproponowanym przez Almona ${ }^{32}$ (1991):

- konstrukcja bottom-up: model wyjaśnia zjawiska ekonomiczne na szczeblu sektorów, a następnie wielkości sektorowe są agregowane do wielkości makroekonomicznych;

32 C. Almon, The INFORUM approach to interindustry modeling, Economic Systems Research 1991/3/1, s. 1-7; zob. też M. Plich, Budowa ..., s. 161-162. 
- uwzględnienie specyfiki sektorów: równania dla różnych sektorów mogą mieć (i najczęściej mają) podobną specyfikację, ale parametry są zróżnicowane sektorowo;

- dynamizacja modelu: dokonywana jest poprzez uzmiennienie współczynników i-o (input-output), uzależnienie inwestycji od tempa produkcji, równania długookresowej wydajności pracy uzależnionej od czasu, etc.;

- modelowanie prognostyczne: celem modeli jest prognozowanie/symulowanie wielkości ekonomicznych w kolejnych latach, a nie stanu równowagi, który miałby być osiagnięty w nieokreślonej przyszłości;

- modelowanie składowych popytu finalnego: składowe popytu finalnego (konsumpcja, inwestycje, eksport) dekomponowane są na kilkanaście do kilkudziesięciu kategorii i objaśniane za pomocą równań stochastycznych;

- zastosowanie równań produkcji analizy i-o: równania te zapewniają wewnętrzną zgodność prognoz przez spełnienie odpowiednich tożsamości bilansowych;

- zastosowanie równań cen analizy i-o: przyjmuje się kosztową formułę w modelowaniu cen;

- modelowanie nakładów czynników pierwotnych: elementy wartości dodanej są modelowane w układzie sektorowym przy wykorzystaniu równań stochastycznych;

- powiązanie sfery realnej i nominalnej: powiązania dokonuje się np. uzależniając elementy wartości dodanej od realnej wielkości produkcji czy inwestycji; sfera realna uzależniona jest z kolei od cen relatywnych (popyt końcowy, współczynniki i-o);

- wykorzystanie szeregów czasowych do szacowania parametrów: parametry równań opisowych szacowane są głównie na podstawie danych historycznych pochodzących z szeregów czasowych;

- wspólne oprogramowanie: operacyjne wersje modeli Inforum są implementowane komputerowo przy użyciu tego samego pakietu programów (Interdyme); dzięki temu modele mogą być łączone w system modeli Inforum za pomocą macierzy BTM ${ }^{33}$.

Wysoki jak na modele gospodarki stopień szczegółowości modeli WMM (duża liczba wyróżnionych sektorów) i nie zobowiązująca (w porównaniu

33 Akronim oznaczający Bilateral Trade Model, więcej na ten temat w: R. Bardazzi, L. Ghezzi, Towards a new INFORUM Bilateral Trade Model: Data issues and modelling questions, w: R. Bardazzi, L. Ghezzi (red.), Macroeconomic Modelling for Policy Analysis, Firenze University Press, 2013, s. 3-42 oraz D.E. Nyhus, The INFORUM international system, Economic Systems Research 1991/3/1, s. 55-64. 
z modelami CGE) konstrukcja równań modelu powodują, że można je łatwo rozbudowywać. Po dołączeniu odpowiednich równań każdy sektor może stać się przedmiotem odrębnych analiz. W takim ujęciu pozostałe sektory tworzą mezoekonomiczne tło dla tych analiz. Zauważmy, że możliwość dołączenia dodatkowych równań opisujących funkcjonowanie wybranego sektora zależy od dostępności odpowiednich danych. Ta własność modeli WMM jest szczególnie cenna w przypadku sektora energetycznego, bo jest punktem wyjścia do konstrukcji równań popytu na energię, które mogą być zintegrowane z modelem WMM.

\subsection{Równania popytu na energię}

Podstawą konstrukcji równań popytu na energię są dane pochodzące z bilansów energetycznych ${ }^{34}$. Przedstawiają one zużycie energii w ujęciu krzyżowym - według sektorów i nośników energii. Zastosowana tam klasyfikacja nie jest wprawdzie w pełni zgodna $\mathrm{z}$ klasyfikacją używaną w tablicach input-output, ale dane z obu źródeł można zharmonizować ${ }^{35}$. Zharmonizowane dane stanowią podstawę do rozbudowy modeli ekonomicznych o równania popytu na energię wyrażoną ilościowo, które przyjmują następującą postać:

$$
E_{f j t}=v_{f j t} \cdot a_{(f) j t} \cdot X_{j t}, \quad(j=1, \ldots, J),(f=1, \ldots, F),(t=1, \ldots, T),
$$

gdzie:

$E_{f j t}$-zużycie paliwa $f$ przez $j$-ty sektor (w jednostkach fizycznych) w okresie t, $x_{(f) j t}$-zużycie produktu sektora paliwowego wytwarzającego paliwo $f \mathrm{w} j$-tym sektorze w okresie t (w jednostkach pieniężnych),

$v_{f t t}=\frac{E_{f f t}}{x_{(f) j t}} \quad-$ współczynnik zużycia paliwa $f$ w nakładach produktu $(f)$-tego sektora (tj. sektora wytwarzającego paliwo $(f)$, zużywanych w j-tym sektorze w okresie t,

$a_{(f) j t}=\frac{x_{(f) j t}}{X_{j t}}-\begin{aligned} & \text { współczynnik bezpośrednich nakładów } \mathrm{w} \text { pochodzących } \\ & \mathrm{z}(f) \text {-tego sektora } \mathrm{w} j \text {-tej gałęzi w okresie } \mathrm{t},\end{aligned}$

$X_{j t}-$ produkcja globalna $j$-sektora w okresie $t$,

34 W Polsce publikowane są one rokrocznie przez GUS pod nazwą „Gospodarka paliwowo-energetyczna" (zob. Gospodarka..., 1997 i n.).

35 Zob. M. Plich, J. Skrzypek, Trendy... 
$J$ - liczba sektorów,

$F$ - liczba rodzajów energii,

$S$ - subskrypt Czasu.

O współczynnikach $v$ zakłada się zwykle, że są stałe ${ }^{36}$, co wynika z ich charakteru. Współczynniki $v$ liczone są dla $j$-tego sektora jako iloraz ilości zużytego w nim paliwa $f$ i wartości nakładów na produkty pochodzące z sektora produkującego to paliwo, wyrażonej w cenach stałych (wolumenu nakładów). Okres będący podstawą do wyznaczenia wartości w cenach stałych oznaczmy symbolem, $0 " 37$. Gdyby paliwo $f$ było jedynym produktem sektora $(f)$ dostarczanym do $j$-tego sektora, wówczas odwrotność współczynnika $v$ byłaby ceną nabycia jednostki paliwa $f$ przez $j$-tą gałąz w okresie 0 . Ponieważ wolumen nakładów pokazuje $-\mathrm{z}$ definicji - zmiany ilości przedstawione wartościowo (w cenach stałych), więc można byłoby powiedzieć, że zarówno licznik, jak i mianownik współczynnika $v$ charakteryzują zmiany ilości (choć w odmienny sposób). Prowadzi to do wniosku, że współczynniki $v$ są stałe przy powyższym założeniu. W sytuacji, gdyby sektor $(f)$ dostarczał do $j$-tego sektora również inne produkty, nie można byłoby stwierdzić jednoznacznie, że współczynniki $v$ są stałe, bo zależałyby one również od relacji cen i struktury zużycia produktów sektora $(f)$ przez j-ty sektor. Najczęściej przyjmuje się, że są one stabilne.

Założenie o stałości współczynników $a$ jest zgodne z klasycznym podejściem Leontiefa, ale z drugiej strony istnienie szeregów czasowych współczynników bezpośrednich nakładów umożliwia oszacowanie parametrów modeli opisujących ich zmienność. Konstruując model opisowy, w typowej specyfikacji uzależnia się współczynniki nakładów od cen relatywnych i zmiennej czasowej:

$$
a_{(f) j t}=f\left(\frac{p_{f i}}{p_{I t}}, t\right),
$$

gdzie:

$p$ - ceny,

$I$ - inne paliwa.

Model typu WMM dla gospodarki Polski rozbudowany o zaprezentowany tutaj blok równań popytu na energię był już wykorzystywany do takich analiz, jak wpływ zmian strukturalnych na emisję zanieczyszczeń powietrza ${ }^{38}$, wpływ

36 Por. M. Plich, Budowa ..., s. 212-213.

37 Wybór okresu podstawowego podyktowany jest zwykle dostępnością tablicy input-output.

38 M. Plich, Budowa... 
zmian cen energii na polską gospodarkę ${ }^{39}$, skutki wprowadzenia handlu zanieczyszczeniami ${ }^{40}$, skutki wydobycia gazu łupkowego w Polsce ${ }^{41}$.

$\mathrm{Na}$ koniec zauważmy, że jeśli dane o energii będące podstawą konstrukcji powyższych równań zostałyby zharmonizowane z danymi modelu inżynierskiego, to projekcje popytu na energię wygenerowane przez model WMM mogłyby zasilać model inżynierski. Jest to pierwszy krok do sprzęgnięcia obu modeli i utworzenia modelu hybrydowego, który zdefiniowaliśmy w punkcie 4.

\section{Podsumowanie}

Z przeprowadzonego wywodu wynikają następujące wnioski:

1. System energetyczny jest ważnym elementem gospodarki narodowej, z którą łączy go wiele powiązań o charakterze sprzężeń zwrotnych. W wyniku wyczerpywania zasobów energii nieodnawialnej i wzrostu kosztów emisji zanieczyszczeń powiązania te stają się coraz intensywniejsze.

2. Konstrukcja modeli energetycznych powinna uwzględniać dwa wzajemnie ze sobą powiązane bloki - ekonomiczny i energetyczny. Zasady ich modelowania wywodzą się z odmiennych tradycji i zależą od potrzeb oraz dostępności danych. Integracja obu bloków w ramach jednego modelu zwykle wymaga rozwiązania licznych problemów natury metodologicznej, statystycznej i informatycznej. Większość kryteriów przedstawianych w literaturze w kontekście klasyfikacji modeli energetycznych ma zbyt ogólny charakter, bo dotyczy wszelkich modeli matematycznych lub ekonomicznych. Zdaniem autorów, specyfikę modeli energetycznych oddają trzy następujące kryteria: a) sposób łączenia bloku energetycznego z blikiem ekonomicznym (soft-link, hard-link),

39 M. Plich, Modeling Economic and Social Impacts of Energy Prices in the Polish Economy, w: idem, Recent developments in INFORUM-type Modeling, Wydawnictwo Uniwersytetu Łódzkiego, Łódź 2007, s. 53-68; J. Boratyński i in., Krótkookresowe efekty zmian cen energii w polskiej gospodarce, Studia Prawno-Ekonomiczne 2010/LXXXII, s. 217-240.

40 M. Plich, Sectoral Impact of EU2020 Targets on the Polish Economy, w: T. Hasegawa, M. Ono (red.), Interindustry Based Analysis of Macroeconomic Forecasting, Institute for International Trade and Investment, Tokyo 2011, s. 42-61.

${ }^{41}$ M. Plich, Determinants of Modelling the Impact of Possible Shale Gas Extraction in Poland, w: R. Bardazzi, L. Ghezzi (red.), Macroeconomic Modelling for Policy Analysis, Firenze University Press, 2013, s. 245-270; M. Plich, The Impact of Possible Shale Gas Extraction on the Polish Economy, w: D.S. Meade (red.), In Quest of the Craft: Economic Modeling for the 21st Century, Firenze University Press, 2015, s. 79-102. 
b) stopień szczegółowości (dezagregacji) danych użytych do budowy modelu,

c) podejście analityczne (bottom-up, top-down).

3. Bloki energetyczne budowane zgodnie z podejściem inżynierskim charakteryzują się bardzo wysokim stopniem szczegółowości, niedostępnym w przypadku bloków ekonomicznych. Aby nie ograniczać jakości wyników całego modelu, blok ekonomiczny powinien wykorzystywać podejście wielosektorowe, bazujące na danych z tablic input-output. W zależności od teorii ekonomicznej leżącej u podstaw konstrukcji modelu wielosektorowego wyodrębnia się modele CGE bazujące na teorii neoklasycznej oraz modele WMM wykorzystujące teorię neokeynesowską.

4. Modele WMM, w przeciwieństwie do modeli CGE, nie koncentrują się na osiaganiu przez gospodarkę stanu równowagi, ale na dynamice jej rozwoju. Pozwalają zatem śledzić w sposób systematyczny zmiany zachodzące w gospodarce. Mogą być łatwo rozbudowywane dla potrzeb analiz wybranych aspektów funkcjonowania gospodarki. Ponadto, w przeciwieństwie do modeli CGE nie są skrępowane sztywnymi założeniami teoretycznymi dotyczącymi postaci funkcyjnych stosowanych równań. Modele WMM stanowią zatem dobrą alternatywę dla modeli CGE najczęściej wykorzystywanych do budowy bloków ekonomicznych w modelach energetycznych.

5. Kolejnym etapem badań nad modelami WMM w kontekście modelowania systemów energetycznych będzie aktualizacja modelu dla gospodarki Polski w oparciu o najnowsze dane i jego wykorzystanie do symulacji przyszłego poziomu zużycia nośników energii i powiązanej z nim emisji zanieczyszczeń na podstawie scenariuszy rozwoju polskiego systemu energetycznego, zawartych w Narodowym Programie Rozwoju Gospodarki Niskoemisyjnej oraz Polityki Energetycznej Polski ${ }^{42}$.

\section{Bibliografia}

Almon Clopper, The INFORUM approach to interindustry modeling, Economic Systems Research 1991/3/1, s. 1-7.

Bardazzi Rosella, Ghezzi Leonardo, Towards a new INFORUM Bilateral Trade Model: Data issues and modelling questions, w: Rosella Bardazzi, Leonardo Ghezzi (red.), Macroeconomic Modelling for Policy Analysis, Firenze University Press, 2013, s. 3-42.

42 Zob. Narodowy Program Rozwoju Gospodarki Niskoemisyjnej, Ministerstwo Gospodarki, Warszawa 2015 oraz Projekt Polityki Energetycznej Polski do roku 2050, Ministerstwo Gospodarki, Warszawa 2014. 
Bataille Chris, Lorna Ann, Bottom-up models of energy: across the spectrum, w: Joanne Evans, Lester C. Hunt (red.), International Handbook on Economics of Energy, Edward Edgar, 2009, s. 257-284.

Bauer Nico, Edenhofer Ottomar, Kypreos Socrates, Linking energy system and macroeconomic growth models, Computational Management Science 2008/5/1, s. 95-117.

Baumgärtner Stefan, Thermodynamic Models, w: John Proops, Paul Safonov (red.), Modelling in Ecological Economics, Edward Elgar, Cheltenham 2004, s. 102-129.

Beeck Nicole Maria Johanna Petronella van, A new decision support method for local energy planning in developing countries, CentER, Center for Economic Research, Tilburg 2003, praca doktorska.

Beeck Nicole Maria Johanna Petronella van, Classification of Energy Models, FEW Research Memorandum. Operations research 1999/777, Tilburg.

Benichou Leo, Mayr Sebastian, Rogeaulito: A World Energy Scenario ModelingTool for Transparent Energy SystemThinking, Frontiers in Energy Research 2014, doi: http://dx.doi. org/10.3389/fenrg.2013.00013

Bhattacharyya Subhes, Timisina Govinda R., A review of energy system models, International Journal of Energy Sector Management 2010/4/4, s. 494-518.

Böhringer Christoph, Combining Bottom-Up and Top-Down, Energy Economics 2008/30/2, s. $574-596$.

Böhringer Christoph, The synthesis of bottom-up and top-down in energy policy modeling, Energy Economics 1998/20/3, s. 233-248.

Boratyński Jakub, Plich Mariusz, Przybyliński Michal, Krótkookresowe efekty zmian cen energii w polskiej gospodarce, Studia Prawno-Ekonomiczne 2010/LXXXII, s. 217-240.

Bosetti Valentina, Golub Alexander $\mathbf{i}$ in., Abatement cost uncertainity and policy instrument selection under a stringent climate policy, w: Golub Alexander, Markandya Anil, Modeling environment - improving technological innovations under uncertainty, Routlege, London and New York 2008, s. 127-157.

Bruce James P., Lee Hoesung, Haites Eric F. (red.), Climate Change 1995. Economic and Social Dimensions of Climate Change, Cambridge University Press, 1996.

Davies Evan G.R., Simonovic Slobodan P., Water resources Research Report. Energy sector for the integrated system dynamics model for analyzing behavior of the social-economic-climatic model, Department of Civil and Environmental Engineering The University of Western Ontario, London 2009.

Deane Paul J., Chiodi Alessandro, Gargiulo Martin, Ó Gallachóir Brian, Soft-linking of a power systems model to an energy systems model, Energy 2012/42/1, s. 303-312.

Frangopoulos Christos, Exergy, Energy System Analysis and Optimization - Volume III: Artificial Intelligence and Expert Systems in Energy Systems Analysis Sustainability Considerations in the Modeling of Energy Systems, EOLSS Publications, 2009.

Frei Christoph W., Haldi Pierre-Andre, Sarlos Gerard, Dynamic formulation of a top-down and bottom-up merging energy policy model, Energy Policy 2003/31(2003), s. 1017-1031.

Gospodarka paliwowo-energetyczna, Główny Urząd Statystyczny (GUS), Warszawa 1997 i n.

Hall Jim W., Nicholls Robert, Tran Martino, Hickford Adrian, The future of national infrastructure: A system-of-systems approach, Cambridge University Press, 2016.

Hall Lisa M.H., Buckley Alastair R., A review of energy systems models in the UK: Prevalent usage and categorization, Applied Energy 2016/169, s. 607-628.

Herbst Andrea, Toro Felipe, Reitze Felix, Jochem Eberhard, Introduction to Energy Systems Modelling, Swiss Society of Economics and Statistics 2012/148/2, s. 111-135. 
Jankowski Bolesław, Modelowanie rozwoju krajowego systemu energetycznego z uwzględnieniem wymagań stabilizacji i redukcji emisji dwutlenku węgla w Polsce, IPPT PAN 1997, praca doktorska.

Kamiński Jacek, Kaszyński Przemysław, Wybrane problemy implementacji zapotrzebowania na moc w matematycznych modelach systemów elektroenergetycznych, Polityka Energetyczna 2011/14/2, s. 155-166.

Kamiński Jacek, Modelowanie systemów energetycznych: ogólna metodyka budowy modeli, Polityka Energetyczna 2010/13/2, s. 219-226.

Kemfert Claudia, Truong Troung, Energy-economy-environment modeling: a survey, w: Joanne Evans, Lester C. Hunt (red.), International Handbook on Economics of Energy, Edward Edgar, 2009, s. 367-382.

Klima Grzegorz, Poznańska Dorota (red.), Model optymalnego miksu energetycznego dla Polski do roku 2060, Departament Analiz Strategicznych. Kancelaria Prezesa Rady Ministrów, Warszawa 2013.

Krzemień Joanna, Zastosowanie generatora modeli MARKAL do optymalizacji systemów energetycznych, Journal of Sustainable Mining 2013/12/2.

Kudełko Mariusz, Znaczenie analizy systemowej w prognozowaniu rozwoju sektorów paliwowo-energetycznych, Polityka Energetyczna 2005/8, zeszyt specjalny, s. 245-260.

Kummel Rainer, The Productive Power of Energy and its Taxation, 4th European Congress Economics and Management of Energy in Industry, Porto 2007, http://energiesteuer.net/artikel/ pdf_artikel/portotalk.pdf; stan na 15.09.2015 r.

Lyżwa Wojciech, Olek Błażej, Wierzbowski Michal, Optymalizacja krajowego miksu energetycznego w kontekście polityki energetycznej, Rynek Energii 2014/5, s. 23-31.

Miller Ronald, Blair Peter, Input-Output analysis. Foundations and Extensions, Cambridge University Press, Nowy York 2009.

Nakata Toshihiko, Energy-economic models and the environment, Progress in Energy and Combustion Science 2004/30, s. 417-475.

Narodowy Program Rozwoju Gospodarki Niskoemisyjnej, Ministerstwo Gospodarki, Warszawa 2015.

Neshat Najmeh, Reza Amin-Naseri Mohammad, Danesh Farzaneh, Energy models: methods and characteristics, Journal of Energy in Southern Africa 2014/25/4, s. 101-111.

Nyhus Douglas E., The INFORUM international system, Economic Systems Research 1991/3/1, s. 55-64.

Peterson E. i in., Panel discussion on the future of national energy modelling, w: William T. Ziemba, Sandra L. Schwarz, Energy Policy Modeling: United States and Canadian Experiences: Volume I Specialized Energy Policy Models, Springer Science \& Business Media 2012, s. 248-266.

Plich Mariusz, Budowa i zastosowanie wielosektorowych modeli ekologicznych, Wydawnictwo Uniwersytetu Łódzkiego, Łódź 2002.

Plich Mariusz, Determinants of Modelling the Impact of Possible Shale Gas Extraction in Poland, w: Rosella Bardazzi, Leonardo Ghezzi (red.), Macroeconomic Modelling for Policy Analysis, Firenze University Press, 2013, s. 245-270.

Plich Mariusz, Modeling Economic and Social Impacts of Energy Prices in the Polish Economy, w: idem, Recent developments in INFORUM-type Modeling, Wydawnictwo Uniwersytetu Łódzkiego, Łódź 2007, s. 53-68. 
Plich Mariusz, Sectoral Impact of EU2020 Targets on the Polish Economy, w: Toshiaki Hasegawa, Matsuhito Ono (red.), Interindustry Based Analysis of Macroeconomic Forecasting, Institute for International Trade and Investment, Tokyo 2011, s. 42-61.

Plich Mariusz, Skrzypek Jurand, Trendy energochłonności sektorów polskiej gospodarki w latach 1996-2012, Wiadomości Statystyczne 2016/7/2016, s. 16-38.

Plich Mariusz, The Impact of Possible Shale Gas Extraction on the Polish Economy, w: Douglas Meade (red.), In Quest of the Craft: Economic Modeling for the 21st Century, Firenze University Press, 2015, s. 79-102.

Plourde Andre, Ryan David L., Empirical modelling of energy demand, w: Joanne Evans, Lester C. Hunt (red.), International Handbook on Economics of Energy, Edward Edgar, 2009, s. $112-143$.

Pluta Marcin, Mirowski Tomasz, Wyrwa Artur, Zyśk Janusz, Wyniki wstępnych badań nad dlugookresowym rozwojem krajowego system wytwarzania energii elektrycznej $w$ Polsce, Polityka Energetyczna 2012/15/4, s. 85-96.

Projekt Polityki Energetycznej Polski do roku 2050, Ministerstwo Gospodarki, Warszawa 2014.

Próchnicki Lech, Nowa szkoła Keynesowska - teoretyczne i polityczne implikacje, Studia i Prace WNEiZ 2011/16, s. 67-89.

Rath-Nagel St., Voss Alfred, Energy models for planning and policy assessment, European Journal of Operational Research 1981/8/2, s. 99-114.

Rathore N.S., Pawnar N.L., Renewable Energy Sources for Susutainable Development, New India Publishing Agency, New Delhi 2007.

Rechul Halina, Systemowe spojrzenie na energetykę. Przedmiot polityki energetycznej, Nafta i Gaz Biznes 2005, nr marcowy, http://www.cire.pl/pliki/2/sys_energ.pdf; stan na 15.05.2016 r.

Rodrigues Renato i in., Energy-economic-environmental models: a survey, w: Ibon Galarraga, Mikel González-Eguino, Anil Markandya (red.), Handbook of Sustainable Energy, Edward Elgar Publishing, 2011, s. 132-160.

Shukla P.R., Review of linked modelling of low-carbon development, mitigation and its full costs and benefits, Mitigation Action Plans \& Scenarios, 2013.

Suwała Wojciech, Problemy ekonomiczne modelowania systemów paliwowo-energetycznych, Polityka Energetyczna 2010/13/2, s. 435-448.

Suwala Wojciech, Typowe elementy i modele systemów paliwowo-energetycznych, Zeszyty Naukowe Instytutu Gospodarki Surowcami Mineralnymi i Energii Polskiej Akademii Nauk 2009/76/2009.

Szczerbowski Radosław, Modelowanie systemów energetycznych - charakterystyka wybranych modeli, Polityka Energetyczna 2014/17/3, s. 147-156.

Thompson Henry, The applied theory of Energy substitution in production, Energy Economics 2006/28/4, s. 410-425.

Timmerman Jonas, Vandevelde Lieven, Van Eetvelde Greet, Towards low carbon business park energy systems: Classification of techno-economic energy models, Energy 2014/75, s. $68-80$.

Urban F., Benders R.M.J., Moll H.C., Modelling energy systems for developing countries, Energy Policy 2007/35 (2007), s. 3473-3482

Werling Jeffrey Francis, MIDE: a macroeconomic multisectoral model of Spanish economy, Faculty of the Graduate School of The University of Maryland 1992, praca doktorska, http:// ma.umd.edu/papers/publishedwork/dissertations/werling.pdf; stan na 20.05.2016 r. 
Mariusz PLICH

Jurand SKRZYPEK

\section{THE USE OF MULTISECTORAL MACROECONOMIC MODELS IN NATIONAL ENERGY SYSTEMS MODELLING}

( Sum mary)

Energy models are an important research tool for socio-economic development, especially in the context of the energy security, natural resources depletion and the climate policy. The purpose of this paper is to identify desirable features of these models and, on this background, to point the properties of multisectoral energy models, which determinate their suitability of energy models construction.

In the article we are presenting the energy system as a separated part of economic processes, what is mirrored in the energy models, in the form of an energy and economic block separation. The analysis of the classifications, known from the literature, leads to a conclusion, that the role of the economic blocks is usually - but wrongly - marginalized. High degree of detail, which characterizes the energy models, should encourage to construct the economic block with an application of multisectoral approach, with the highest level of disaggregation - this has a positive effect on the quality of blocks integration. We emphasize the role of multisectoral macroeconomic models in that context by analyzing their basic properties and presenting the example form of energy demand equations, whose results can directly power the energy block.

Keywords: energy market; energy models; input-output methods; multisectoral models 